\title{
GENTRIFICATION AND THE GRASSROOTS: POPULAR SUPPORT IN THE REVANCHIST SUBURB
}

\author{
CHRISTOPHER NIEDT \\ University of California, Berkeley
}

\begin{abstract}
Most existing research on neighborhoods facing gentrification has portrayed residents as resistant or politically quiescent. Drawing from a year of fieldwork in Dundalk, $M D, I$ argue that developers and the neoliberal state will probably find popular support for gentrification as they reinvest in the politically divided industrial suburbs of the United States. Local homeowners and community associations have emerged as gentrification supporters for three interrelated reasons. First, many of them have drawn from a resurgent national conservatism to explain decline as an effect of government subsidies and "people from the city;" their desire to reclaim suburban space - a "suburban revanchism"-although avoiding accusations of racism makes gentrification-induced displacement appealing. Second, the rebirth of urban neighborhoods and other industrial suburbs provides visual evidence of gentrification's success. Third, the neoliberal state's retreat from social programs and its emphasis on private-sector redevelopment allay suspicion of government and enable collaboration between the local state, developers, and homeowners. The redevelopment efforts of two local organizations illustrate how residents have become indispensable partners in Dundalk's emergent pro-gentrification coalition.
\end{abstract}

G entrification studies have long given center stage to debates among scholars who emphasize economic or cultural causal forces. Despite these differences, a wide swath of research describes a similar political field. Elite actors-banks and developers, yuppies and artists, and planners and politicians - drive gentrification, and researchers give their varied political positions considerable attention. Existing residents respond to the process with broad resistance or quiescence, and researchers focus instead on the preconditions and effects of their responses.

But the complex divisions within this second group are becoming critical, as gentrification diffuses to the older suburbs of the United States. Drawing on a year of interviews, archival research, and participant observation in the Baltimore suburb of Dundalk, MD, I argue that white working-class homeowners are likely to be key gentrification proponents. I use Jason Hackworth's recent work on gentrification's "third wave" to identify emergent trends in gentrification generally (Hackworth \& Smith, 2001; Hackworth, 2002). Subsequent sections explain the emergence of popular support for gentrification as the result of three factors: the "revanchism" of homeowners who seek to reclaim suburban

Direct Correspondence to: Christopher Niedt, 1943 Rose Street, Berkeley, CA 94709. E-mail: niedt@berkeley.edu.

JOURNAL OF URBAN AFFAIRS, Volume 28, Number 2, pages 99-120.

Copyright (C) 2006 Urban Affairs Association

All rights of reproduction in any form reserved.

ISSN: 0735-2166. 
space from "people from the city"; the visual transformation of nearby urban and suburban neighborhoods; and the neoliberal state's support for renter clearance, which reassures local residents wary of government action. My case study illustrates the confluence of these factors within two local community associations that have been proponents of neighborhood change in Dundalk. I conclude with a brief discussion of implications for future research.

\section{"THIRD-WAVE" GENTRIFICATION: THE USUAL SUSPECTS?}

We can define gentrification, broadly, as a process by which wealthier, more privileged residents and new land uses (those that attract and are supported by the new residents) replace poorer, less privileged residents and older land uses. As Loretta Lees (1994, 2000) and others have observed, however, gentrification's form varies considerably across time and place. What, then, are its contours, as it advances on the older suburbs of the United States? A good point of departure is the work of Jason Hackworth (2002; see also Hackworth \& Smith, 2001), who periodizes gentrification into historical waves: a first wave of state-supported, sporadic gentrification in larger cities; a second wave in which localized gentrification became integrated into global and national scale processes, as the state retreated to a laissez-faire position; and a third wave that followed the recession of the early 1990s. Synthesizing other recent studies with his own New York research, Hackworth argues that postrecessionary gentrification in the United States exhibits four noteworthy features: a dominance of corporate developer capital, renewed pro-gentrification intervention by the neoliberal local and national state, diffusion of the process to places far removed from the central business district, and waning antigentrification activism.

Hackworth argues that the corporatization of gentrification emerged from two countervailing factors. First, most easily gentrifiable neighborhoods have been exhausted, and the risk and entry costs associated with investment in other neighborhoods have discouraged individual gentrifiers (Hackworth \& Smith, 2001). Second, the integration of the finance and real-estate sectors, together with the consolidation and globalization of finance capital in the wake of the early 1990s recession, has concentrated the capital of developers now willing and able to pioneer in difficult neighborhoods.

Those developers find enthusiastic partners in interventionist local administrations, who embrace gentrification as a growth strategy (Smith, 2002). Over the course of the 1970s and 1980s, capital flight, mounting service costs, and federal cuts to urban aid sunk many cities into fiscal distress. Although originally forced to scale back their role in social reproduction (Katz, 2002), many local states internalized the supply-side policy approaches that had justified federal welfare state retrenchment (Brenner \& Theodore, 2002). Accordingly, they began to pursue entrepreneurial growth strategies, explicitly remaking their downtowns to better compete for global capital, tourist traffic, and upper-income residents (Harvey, 1989; Levine, 1987).

Housing policy has been central to these strategies. At the federal level, pressure for privatization contributed to a long-term shift from federally regulated, in-kind public housing provision to block grants and vouchers (Goetz, 2003; Hays, 1995). This slow trend leaped forward when Republicans won control of Congress in 1994 and threatened to eliminate HUD; the Clinton administration responded by intensifying the drive toward voucherization and speeding the demolition and reconstruction of existing projects under the HOPE VI program (Cisneros, 1996; Goetz, 2003; Rusk, 1999). HOPE VI interacted with gentrification as both cause and effect. At some sites, nearby gentrification produced 
a market that made HOPE VI's mixed-income reconstruction feasible (Wyly \& Hammel, 1999); the new projects' low-rise design, in turn, may have removed aesthetic and social obstacles to further gentrification. Additionally, neoliberal federal housing policy has sung the virtues of homeownership - a concept with broad and historically rooted appeal in the Unites States (Dreier, 1982; Harris, 1990) — although some studies have suggested that low-income homeownership initiatives and even the anti-redlining Community Reinvestment Act may facilitate gentrification (Newman \& Ashton, 2004; Wyly \& Hammel, 2004).

The cooperative relationship between corporate developers and the neoliberal state has facilitated gentrification's continued spatial diffusion during the third wave (Smith \& DeFillipis, 1999). Most low-risk neighborhoods with large rent gaps - often neighborhoods close to the urban core - have already been gentrified. State subsidies now facilitate new investment in riskier areas with higher actualized rents and/or questionable locational advantages.

As gentrification has expanded and intensified, antigentrification activism has waned. Earlier activists often won concessions from urban politicians mindful of the political power of social movements. With the rise of gentrification as a prime growth strategy, opposition has polarized into the confrontational and the co-opted. Militant groups have been frustrated by political intransigence and by the application of police power to clear urban space (Smith, 1996). Community development corporations, which receive much of their funding from public sources, have been particularly disinclined to challenge local development agendas (Newman, 2004; Stoecker, 1997).

In addition, Hackworth (2002) observes that prior rounds of gentrification have weakened activism by lowering working-class density. The threat of mass displacement once held the potential to catalyze political action in neighborhoods where most residents bore the brunt of racist and antipoor policy guided by both the reasoned state retreats of neoliberalism and the more visceral, punitive "revanchism" of a white upper-middle class determined to retake the city (I borrow the term from Smith, 1996; also see Slater, 2002). Whether solidarity led to successful opposition depended on a range of factors, including the discourses, resources, and scalar strategies of local organizations (Betancur, 2002; Mele, 2000; Smith, 1992; Wilson, Wouters, \& Grammenos, 2004).

With the arrival of new residents, however, gentrification can become a divisive local issue that hinges on local interorganizational conflicts, political cleavages, and discourses of decline (Betancur, 2002). In some cases, early gentrifiers, including artists, have joined the activists in drawing a line against gentrification by newer in-migrants. In others, gentrifiers have undermined local solidarity by favoring, or at least allowing, the continued displacement of people and land uses that they find undesirable as neighbors (Betancur, 2002; Curran, 2004; Levine, 2004).

Still more interesting are the supportive existing residents who linger on the periphery of gentrification narratives. We glimpse them, for instance, in Wilson, Wouters, and Grammenos's (2004) account of Chicago's Pilsen area, where some working-class Latino merchants have broken community solidarity to upscale their stores. They also appear in the form of local small builders who purchase and convert property, in the abstracted class analysis of Bridge (1995). Peterman (2000) gives a more grounded account of how the ambivalence of existing homeowner members led to community organization inaction in Chicago's West Town neighborhood, and Mele's (2000) monograph on the Lower East Side describes similar political divisions between antigentrification activists and "oldtimers" who support redevelopment and homeless clearance. But in most case studies, these agents appear as outliers in an otherwise united community, as the exceptions that prove the rule. 
The diffusion of gentrification turns this relationship on its head. As developers and the state think cooperatively and creatively about where next to reinvest, they are exploring locations with smaller rent gaps, partially disinvested places where economic decline and social change have produced deep political cleavages rather than communities united in their vulnerability. In these places, many residents may become gentrification's leading proponents, and mass popular support becomes a possibility that demands consideration.

\section{CONTEXT: THE POLITICAL ECONOMY OF THE U.S. INDUSTRIAL SUBURB}

Where might opportunities for reinvestment and political consent overlap spatially? One possibility is the older, industrial suburb of the United States, where factories that once attracted worker-residents, a web of secondary producers, and retail trade have downsized or closed operations. Industrial disinvestment and the withdrawal of mortgage capital have depressed land values (Hudnut, 2003; Smith, Caris, \& Wyly, 2001). The surfeit of cheap land offers developers a possible suburban rent gap, although the questionable potential rent of older suburban sites poses substantial investment risk. Distance from the urban core, unfashionable architecture, and the industrial reputation of the community may affect the marketability of residential and commercial space. But state interventions and subsidies can compensate for this risk as can the waterfront location of underutilized residential and industrial property in some older suburbs. Environmental degradation may likewise represent a barrier to profitable redevelopment but keeps land vacant until a capital (or state subsidy) capable of performing remediation steps in.

The political potential for resident-supported gentrification is more complex. Insofar as the older suburbs retain concentrations of the white working class, local discourses often reflect ambivalence regarding the root issues that make gentrification controversial, among them the proper role of government, regulation of the free market, protection of industry, and persistence of racism. At its most progressive, U.S. white working-class politics reflects deeply rooted ideas about workers' rights to social wages and social reproduction developed during the days of the New Deal, militant unionism, and the postwar social contract. Moreover, the close institutional relationship between unions and political clubs in those "blue collar communities" where people both lived and worked reinforced a local politics that bucked the division between workplace and residential politics found elsewhere in the United States (Kornblum, 1974; cf. Katznelson, 1981).

But when the reservation of these guarantees as white privileges - the "right" to segregated housing, education, and employment-became untenable in the 1950s and 1960s, their defense became an impetus for conservative resurgence (Durr, 2003; Formisano, 1991; Sugrue, 1996). Although white upper-middle class suburbs were important for the development of conservative resources and repertoires (McGirr, 2001), less affluent suburbs became key sites where conservative activists rallied popular support. The presidential campaigns of George Wallace, Barry Goldwater, and Richard Nixon reconfigured discourses of explicit, anti-integrationist white supremacy into new ones that opposed liberal elitism and federal civil rights enforcement (Carlson, 1981; Durr, 2003; Edsall \& Edsall, 1991). However lightly these discourses veiled the defense of white privilege, they yielded conservatives popular support as civil rights activists pushed for an array of compensatory reforms, the costs of which fell upon-or were perceived to fall uponthe white working class.

The economic crises that racked the Fordist accumulation regime in the 1960s and 1970s further undermined white working-class allegiance to unions and to the liberal Democratic coalition. As primary sector businesses faced declining rates of profit, 
government failed to prevent corporate bankruptcies, offshoring, and the layoffs that resulted from both. As blue-collar workers rapidly lost faith in union effectiveness and state protections, conservatives were able to portray the state's welfare functions as redistributing resources away from working-class whites and toward people of color, the very poor, and "special interests." This climate of resentment, inflationary pressures, and rising property tax bills sparked tax revolts that began in California and spread across the country, feeding antigovernment and antipoor rhetoric (Edsall \& Edsall, 1991).

The movement to radically change government's relationship to the nonelderly poor gained adherents across the political spectrum during the 1980s, with consequences for federal and local urban policy. Reagan, among others, advocated a new "colorblind" neoliberal racial order (Omi \& Winant, 1994) that refined antiwelfare discourse and expanded its political base by emphasizing individual and collective behaviors over structural inequality; behavior defined an "underclass" that, depending on political context, could be characterized either as morally lapsed and in need of punishment or as pathologically dependent and in need of market incentives (Katz, 1989). Both the approaches informed policy that attempted to "fix" poverty by "fixing" the terrifying urban landscapes represented in the mainstream media (Vale, 1995). Punitive discourses resonated with "revanchist" desires to reclaim urban space and justified the unrepentant clearance of the marginally housed (Smith, 1996). Neoliberal policy reforms emphasized a government retreat from housing provision, along with a deconcentration of public housing residents that intended to expose the poor to less pathological middle-class neighbors (Crump, 2003; Goetz, 2003).

Residents of the industrial suburbs, meanwhile, were becoming unable to confine poverty within urban boundaries. As employers departed, personal income and buying power fell, and commercial spaces deteriorated. Soft housing markets were softened further, as sprawl pulled residents and mortgage capital away from older suburbs generally (see Lee \& Leigh, 2005 for debate on this point). Declining rents and values gave people of color, including recent immigrants, access to inner suburbs where de facto segregation had persisted; housing assistance recipients - who began to receive vouchers in 1975 and portable vouchers in 1987-found available apartments where they had once been excluded. These demographic changes allowed wealthier, white residents to use national antiurban and anti-immigrant discourses to explain local problems in terms of "invasion," even though poverty, crime, drug use, and declining property values had in situ explanations. Although research in the older suburbs is lacking, fears of invasion have prompted class and racial succession in some industrial suburbs (Nicolaides, 2002). In others, my case included, these demographic and discursive shifts politically divided white homeowners from other residents, especially the intersecting groups of renters, people of color, and Section 8 recipients (cf. Poindexter, 2000). Where these divisions run deepest, some white homeowners have adopted a politics of "suburban revanchism" - a visceral desire to retake suburban space-manifested at the local level.

Support for upscale construction in the industrial suburbs thus is likely contingent not just on which parties stand to benefit financially from gentrification but on how skillfully proponents (and opponents) respond to these discourses of local decline. Economic instrumentality undoubtedly plays a role: those homeowners who see their homes primarily as exchange values and who can afford higher property taxes may face strong financial incentives to support upscale redevelopment. It is doubtful, however, that this rationale alone would produce consistent support, especially among the groups and constituencies with organized political power. Homeowners might be skeptical about which types of redevelopment will yield them rising property values; they might suspect, for example, that 
upscale newbuild housing planned near a "problem" apartment complex would remain unsold and succumb to devaluation. Nor would those who do not plan to exit the community be necessarily receptive to the limited promise of rising property values, unless articulated with a discourse of community improvement. Discourses of community improvement - which present more comprehensive solutions to the problems identified/ created by discourses of decline-are as essential to building community support for redevelopment as discourses of community protection are to building opposition (cf. Wilson, Wouters, \& Grammenos, 2004).

Gentrification-when articulated as a deliberate strategy of replacing problem people and land uses with affluent property owners and higher-value land uses-offers several advantages as a discourse of community improvement in the industrial suburbs. First, as a private-sector strategy, it is compatible with reductions in government spending that have become broadly popular in the American suburbs (Gainsborough, 2001); the state intervention of third-wave gentrification is acceptable insofar as it facilitates private development. Second, pro-gentrification discourse enables white homeowners and merchants to avoid (often simplistic) accusations of racism by emphasizing the expected positive qualities of incoming residents. Finally, evidence of gentrification's past success is highly visible; it appears to be writ upon urban landscapes transformed during prior waves of reinvestment.

Although in this section I have traced its origins, support for gentrification is not unequivocal. The remnants of Golden Age liberalism, deeply rooted resentments of concentrated economic and political power, and a general pessimism regarding change may provoke opposition. But insofar as pro-gentrification discourse dominates the discussions and guides the actions of politically powerful local constituencies, supportive residents can become key proponents. The next section describes such a case and suggests that residents will become important as third-wave gentrification becomes possible in politically divided inner suburbs.

\section{THE HISTORICAL CONTEXT FOR COMMUNITY CHANGE IN DUNDALK, MD}

Dundalk's suburban history began when World War I era steel demand led to mass in-migration and housing shortages in Bethlehem Steel's Sparrows Point company town and in Baltimore City. Bethlehem Steel collaborated with the U.S. Emergency Fleet Corporation to construct a new community in southeastern Baltimore County, halfway between the plant and the city's eastern border (Figure 1). Deed restrictions balanced residential, commercial, and industrial growth and maintained the area's racial homogeneity; nearly all of the area's African American residents lived in Turner Station, a small enclave on Dundalk's south side. At the end of World War II, Dundalk's spatial order thus reflected white working-class benefits of the postwar social contract-segregated, federally financed suburban homeownership, steady industrial employment, and opportunities for consumption - provided by the liberal welfare state and union representation.

A constellation of unions, political clubs, civil associations, and neighborhood associations mobilized residents around the maintenance of these privileges, as they were felt to be precarious and had to be protected from elites "above" and undesirable residents "below."

Local organizations addressed threats to spaces outside of their formal purview and fused their political interests and organizational repertoires. This overlapping organizational structure, together with a self-contained spatial order, allowed white working-class 


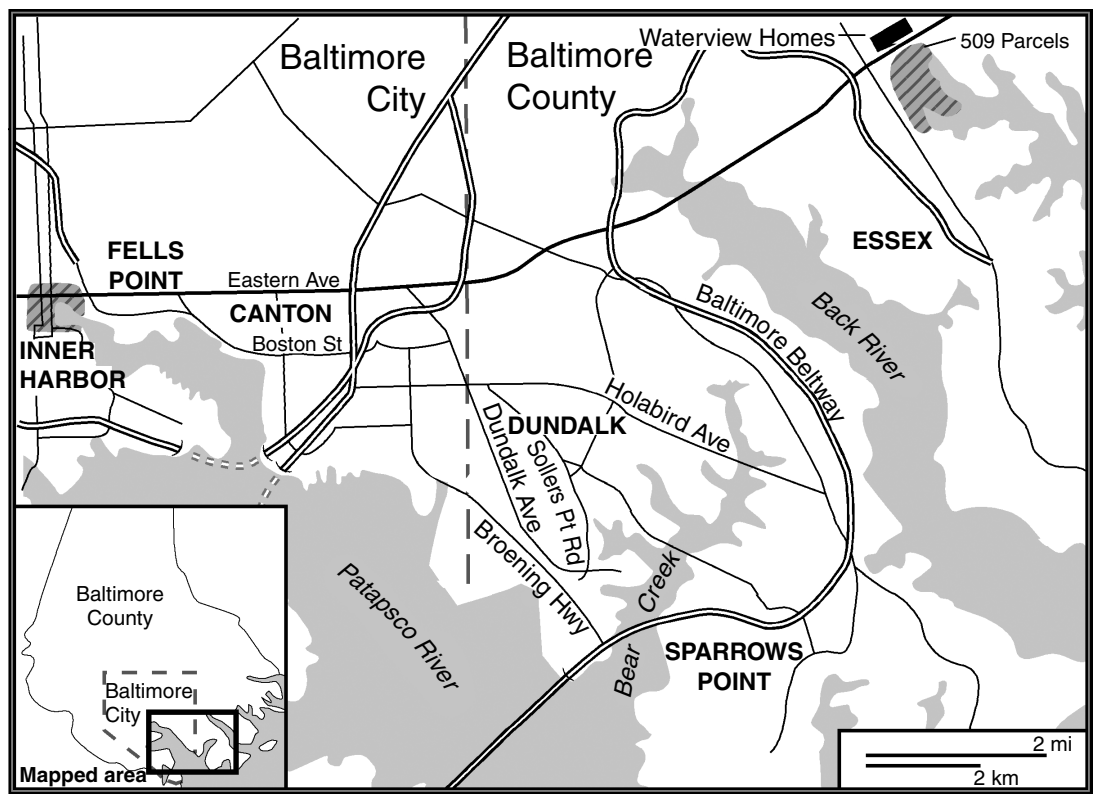

\section{FIGURE 1}

\section{Southeastern Baltimore City and Baltimore County}

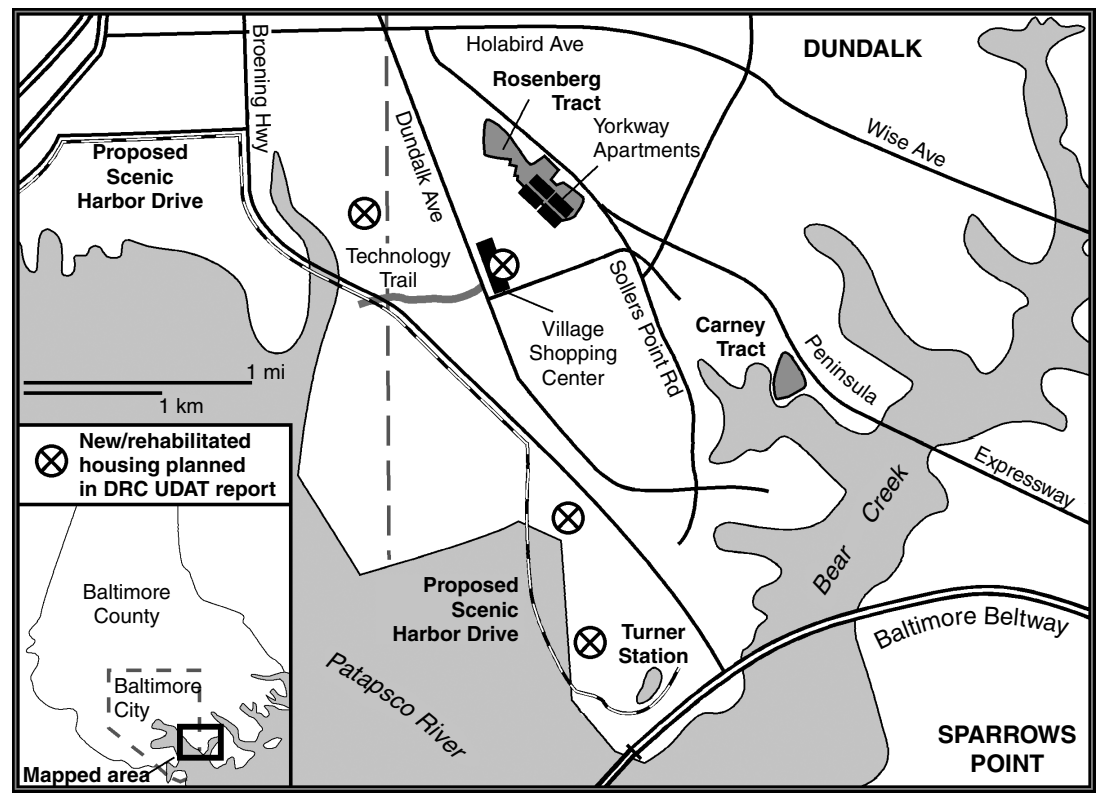

FIGURE 2

\section{A Detail of the Dundalk Area}


men to develop a complex identity through their experiences as workers, residents, and taxpayer citizens.

When civil rights activists began to press for the integration, relief, and empowerment of the black community, public- and private-sector reforms threw these systems of white working-class social privilege and spatial order into crisis. White residents throughout Baltimore County fought against elementary school integration and redistricting and voted down a series of civil rights-related referendum questions between 1964 and 1968 . Southeastern county residents gave heavy support to the segregationist Democratic campaigns of George Wallace (President) and George Mahoney (Governor). In 1966, Mahoney's use of the slogan "your home is your castle" signaled a change in racial discourse at the local scale, as conservative activists began to recognize the liabilities of overt white supremacy and tried to evade them with ostensibly "race-neutral" discourses of homeowner rights, taxpayer rights, law and order, and local control.

The defense of white privilege was well under way when economic and political change began to fray the social contract. Manufacturing employees and their families had long endured work disruption in the form of cyclical layoffs and union strikes, secure in the knowledge that employment would resume, often with increased wages and benefits. This security faded when local factories began a series of plant closures and permanent layoffs in the early 1970s, and employment in generally well-paying production occupations plummeted (Table 1). Household income needs facilitated the entry of local women into the labor force, but because women and displaced men often found work in low-paid service and clerical positions, real household incomes stagnated. Dim employment prospects contributed to the exodus of young baby boomers in the 1970s, a process hastened by a faltering commercial sector and by rising standards for residential space.

Unions and political clubs, the traditional centers of local political power, seemed unable or unwilling to defend white male prerogative in the workplace and community. White workers found the change at Sparrows Point sudden and upsetting. During the late 1960s, civil rights litigation had successfully challenged the steel industry's discriminatory seniority system in federal court, and in 1973, Secretary of Labor James Hodgson issued an order mandating the use of plant seniority. White resentment grew quickly, as many black workers - who had been shut out of skilled jobs by departmental seniority rulestransferred seniority across parts of the plant, sometimes "bumping" white workers with less plant seniority out of their positions and occasionally "leapfrogging" over them altogether. The following year, the United Steelworkers of America signed a consent decree that formalized the plant seniority system while minimizing bumping and leapfrogging. By that point, however, many white workers had become frustrated with the union's failure to pursue grievances related to the new system (Durr, 2003; Nelson, 2001). In the 1980s, productivity partnerships between the union and the Bethlehem Steel management did not staunch layoffs and further dampened militancy.

Nor could residents rely upon the political clubs of Dundalk and Essex, which had dominated county politics throughout most of the postwar Golden Age. Baltimore County's unusual lack of incorporated municipalities made it Dundalk's most local form of government and made county political operators essential for securing public jobs and capital projects. When civil service reform limited patronage and electoral and apportionment changes released county government from machine control, clubs lost considerable power. The perceived responsiveness of county government then fell as economic conditions in the community deteriorated.

The absence of discourses and organizations capable of controlling community life made demographic change a political opportunity for Dundalk conservatives. Demographic 


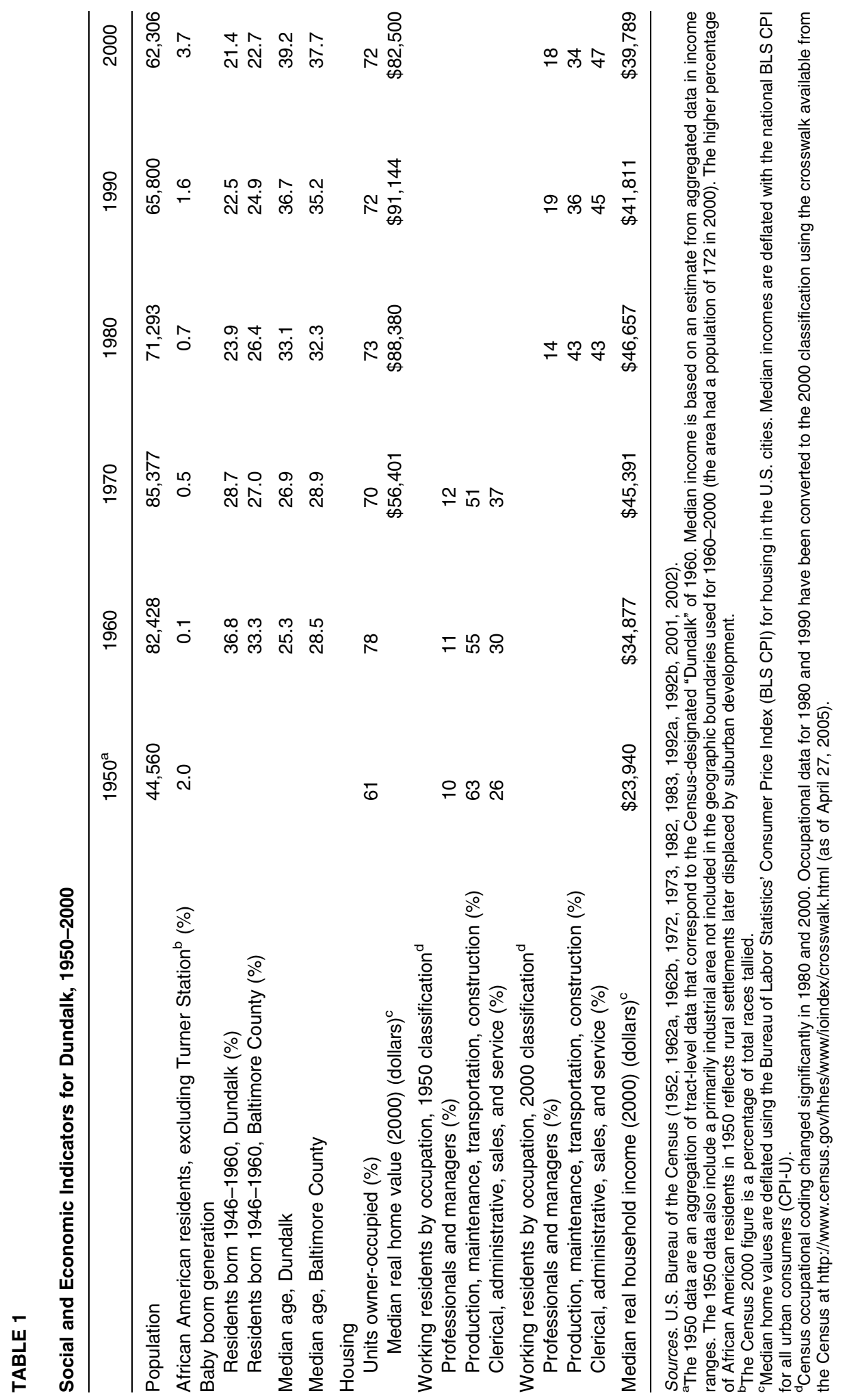


change in Dundalk was hardly dramatic at the place level (Table 1), but these figures do not reflect the growing visibility and concentration of the homeless, poor whites, people of color, and social services near the historic commercial core of the community. For white homeowners nearby, navigating interactions that involved poverty, "racial situations" (Hartigan, 1999), and one's own class and race position became constant projects. Conservatives drew from national antiwelfare and antiurban discourses to feed the perception that "people from the city" were exclusively responsible for Dundalk's problems. Although these problems - among them, crime, drug use, poor property maintenance, and falling property values - were longstanding and geographically dispersed, homeowner politics became increasingly defensive. Many white homeowners began to vigilantly observe neighbors' apparent racial background, class background, and behavior. They exchanged information and conjecture regarding the tenure or welfare status of particular households, especially those suspected of being Section 8 tenants - the dreaded hybrid of renter and welfare recipient supposedly marked by race. White residents were very reluctant to speak about these judgments (or indeed about any explicitly race-related topic) on the record, although some interviewees were willing to characterize the attitudes of the community generally. One member of a local political club, for example, linked Section 8 to both racial stereotypes and real deterioration in housing stock:

the Reagan Democrat conservatives were able to bust up political machines, using fearmongering [. . .] we have all kinds of these colloquialisms for blacks moving into our neighborhoods - high rises, apartments, row homes [. . . ] Turner Station was always the concentrated African American community, and then there was pockets of streets [. . . ] almost like there was a redline around them.

[. . .] Section 8 was again that metaphor for minorities [. . ] whenever a house got dilapidated [. . .] it becomes Section 8, whether it was or wasn't, and the demise of the communities was people leaving the communities and either selling their houses to speculators who rent them out or rent them out themselves, or they lose their jobs and are not able to maintain their property, but that all comes under that big umbrella of Section 8 and MTO [see below] and then as property values fell, rentals started dropping, and you see more and more people being able to afford to move into the Dundalk area, and now there's not those little redlined streets, now it's, 'oh, there's one living in my neighborhood', or 'there's one living down the street from me', you know, that was their mentality (Brooks, 2004).

Although this politics has continued to vie with more paternalistic, sympathetic, and ambivalent attitudes toward tenants and people of color, it is revanchism that has provided the impetus for housing politics in Dundalk's recent history.

Neighborhood, taxpayer, and business associations - previously marginal local actorsturned these discursive shifts into organized action. The timing of their rise to prominence contrasts with organizations in other cities - for example, the Detroit neighborhood associations in Sugrue's account (1996), which wielded significant control within city government during the 1950s and 1960s. In Dundalk, these organizations were tertiary to the political power of political clubs and unions until their consolidation of power in the 1980s and successful mobilizations during the 1990s.

Dundalk's most prominent antitax group, Taxpayers for Government Efficiency, sprang up in the wake of California's successful Proposition 13 and gained support as assessments rose and real incomes slid in the 1980s. In 1990, a grassroots tax revolt united many Dundalk activists with wealthier north county residents and launched a longtime 
antitax crusader into the county council. It also replaced the incumbent county executive with a candidate backed by the organizers of the tax revolt.

Neighborhood associations gained political power, as they rallied residents to defend against perceived threats to their homes: the entry of people of color and the poor, growing tenancy rates, and absentee landlords. In 1994, neighborhood groups successfully fought a federal pilot poverty deconcentration program-Moving to Opportunity (MTO) - which they worried would flood Dundalk with former public housing residents. Two years later, residents mobilized against the dispersion remedies of the Baltimore housing desegregation suit brought by the American Civil Liberties Union (ACLU). In both the cases, media attention seemed to concentrate on white privilege in Dundalk, while ignoring its persistence in other upper-class Baltimore County suburbs. To this day, MTO carries a heavy symbolic weight in Dundalk, signifying the threat posed by public housing, the power of organized homeowners, and the shame at being labeled (fairly or unfairly) a "racist" place.

Business associations promised to attract investment, as government failed to stop the flight of industrial capital. Throughout most of the 1980s, their efforts focused on beautifying and attempting to revitalize the old shopping center, with limited success. They also became ardent defenders of Dundalk's image and political power within the metropolitan region. In 1996, a local businesswoman organized a successful campaign against a Baltimore City deejay who made Dundalk the butt of jokes that drew upon "redneck" and "white trash" imagery. She would later become director of the local Chamber of Commerce and lead a fight that effectively ended city-county state legislative districting in 2002 .

These events set the stage for gentrification. First, they demonstrated the power of homeowner and business interests in Dundalk, and politicians began to bend over backwards demonstrating their commitments to both. Second, the images mobilized against poverty dispersion reinforced neoliberal and revanchist attitudes toward "people from the city." Third, resident resentment at being dismissed as "backward"-whether by MTO proponents, by city officials, or by the deejay - prompted a renewed concern for community image. Merchants and residents formed a new Dundalk Image Group, which soon re-formed as the Greater Dundalk Alliance (GDA). In both incarnations, the group popularized the idea that Dundalk could no longer develop autonomously and had to improve its image if it hoped to attract new residents and investment.

\section{RENAISSANCE AND REVANCHISM: GENTRIFICATION IN THE BEST SENSE OF THE WORD}

If these shifts established conditions for gentrification's popular support, it was a political fight outside of Dundalk - the "509" controversy in nearby Essex-Middle River - that served as gentrification's prelude. It began in early 2000, when then-county executive C. A. "Dutch" Ruppersberger was preparing for a possible run for the Maryland governorship. Attempting to win political support from homeowners and developers, Ruppersberger identified three "blighted" areas in Randallstown (in the west county), Dundalk, and Essex and proposed their eminent domain condemnation and redevelopment. Developer capital had nearly built out the greenfield growth areas that county government had designated in the 1970s and 1980s; vacant land, reasoned Ruppersberger and his Office of Community Conservation, would encourage builders to reconsider the investment possibilities of an eastside that they had long since written off. Residents in Randallstown and Dundalk, at the same time, would be pleased to raze their respective 
symbols of local decline: deteriorating properties along Liberty Road and the crime-ridden Yorkway apartments.

The large parcel on the Essex-Middle River waterfront was more controversial. There, the plan condemned two dilapidated apartment complexes, a number of seashore cottages, and about a dozen businesses. Upscale tourist-oriented shops, hotels, and plazas would take their place. The county executive used his clout to push an eminent domain bill (SB 509) for all the three parcels through the state senate in March 2000 and banked on voters in Dundalk and Randallstown to weather any opposition. Affected residents and businessowners, however, quickly formed Essex-Middle River Community in Action and gained the support of homeowners' associations across the county. Activists lambasted county government for its supposed secrecy, strenuously objected to the classification of their homes and businesses as "blighted," and balked at what they saw as a land grab by big developers. Ruppersberger posed as a true democrat, signing a petition to put the eminent domain bill to referendum. But he sorely underestimated the efficacy of the activists, who launched a media blitz just before the election and defeated 509 by large margins across the county, including the Dundalk precincts.

The aftermath of the vote was more significant than the vote itself. County government had begun to acquire two other troubled, low-rent Essex-Middle River apartment complexes well before the referendum and went forward with clearance plans during the two years that followed. One site was left as parkland, whereas the other was purchased by developer Larry Rosenberg, who moved quickly through the planning process and built the upscale, single-family Waterview Homes. The new housing was visible and popular: it was located along the well-trafficked Eastern Avenue, which connected Essex, Dundalk, and Baltimore City; it was given glowing press in the city's major paper; and its 175 units appreciated in the year it took to sell them. Although Dundalk voters' support for EssexMiddle River homeowners had trumped their desire to see the Yorkway apartments cleared, the Waterview project encouraged them to think more cooperatively about their relationship with developers and county government. Some homeowners began to believe that county planners might sincerely and energetically work in their interests. At the same time, county government was chastened by its defeat at the polls and began to search for ways to ensure community support for redevelopment through participatory processes.

If the Waterview Homes served as an example of what developers and county government accomplish with a single development, then the gentrification of Baltimore City's Canton provided a vision of neighborhood transformation. Canton was a waterfront area that had housed an industrial workforce and had suffered from deindustrialization in the 1970s. But the glittery makeover of the Inner Harbor and the gentrification of the nearby Fells Point inspired a great faith in the power of the waterfront to attract residential and commercial capital, and gentrification crept southeast along the Patapsco River. Developers and individual rehabbers made forays into Canton during the 1980s and arrived in force in the 1990s. Although twentysomething professionals restored brick facades throughout the neighborhood, change was most noticeable along the Boston Street waterfront, where developers converted old plants and warehouses into prime commercial and residential real estate (Merrifield, 2002). Some Dundalk residents had used Boston Street as back route to the city for years and were inspired by the change; a large industrial zone separated the two neighborhoods, but nevertheless, Canton's rejuvenation made Dundalk's gentrification imaginable.

Thus, three related factors explain gentrification's current popularity in Dundalk. First, the success of Canton and Waterview has led local homeowners' groups to view gentrification as positive and possible. Second, developers and county government now share an 
enthusiasm for an eastside redevelopment that responds to community input and generates concrete plans for community change; the potential of a cooperative relationship between community, government, and developers has built popular support. Third, for those homeowners motivated by a revanchist politics, gentrification has resolved the contradictions between a loud, exclusionary discourse of community protection and the desire to improve the community's image; a discourse of community improvement emphasizes the attraction of upper-income professionals rather than the displacement of renters. All three of these factors have been significant to the work of the two community organizations central to present attempts at gentrification: the Dundalk Renaissance Corporation (DRC) and the GDA.

\section{The Dundalk Renaissance Corporation}

The DRC was the brainchild of county government and serves as a good example of the cooperative relationship between county government, developers, and community groups. In 2000, the county's Office of Community Conservation hired Jane Willeboordse, a Baltimore architect experienced with the Urban Design Assistance Team (UDAT) model, a participatory planning approach emphasizing democratic process and community-professional collaboration. County government recruited community leaders for the DRC, which sold memberships to fund an intensive, one-week design workshop (or charette). The DRC reserved a large, centrally located gymnasium, widely advertised the community input sessions, and drew 100-150 participants to each. The design teamcomposed of planners, architects, and economists from the University of North Carolina-began the charette by asking attendees what they wanted to "keep, build, and change." Team members sketched out designs, returned to the community for feedback, refined their proposals, and made a final presentation at the end of the week. The Baltimore County Office of Community Conservation and Office of Planning (2003) then produced a report summarizing the UDAT recommendations, which the DRC subsequently printed, distributed, and used as a guide for its work.

Noteworthy in the plan are the importance of Canton and the role of the neoliberal state. A Scenic Harbor Drive would connect Canton's Boston Street to Dundalk, pulling yuppies and tourists toward waterfront development-including new loft housing, detached single-family housing, a new youth recreation center, a cruise ship pier (with possible adjacent hotel development), a new marina housing development, an ecologic park, a cultural center, and an outdoor Technology Trail of industrial relics (Figure 2). The importance of the Canton connection contrasts with once-dominant local images of Baltimore City as a source of blight. I was not present at the charette sessions, and it is difficult to say how much of the final plan reflected community desires, but a story recounted by Jane Willeboordse suggests that the DRC process helped spark the popular reconceptualization of the city:

Dundalk consistently has been the butt of the jokes, because it was always seen as a very isolated, backward community that wasn't going to pull itself up and become something, and it was one of the first public forums that gave me hope. There was this little older man [. . . who] stood up, and said, 'We've got to get Baltimore City to love us . . . they don't love us!' and they kind of realized [ . . ] you don't have your job center as you did, you don't have your steel factories working the way they did, and I think that's what spurred that comment from this guy. I think the whole crowd heard that, loud and clear. It was very passionate, and it was an eighty-year-old-man saying it. But for me, as 
an optimistic revitalization person sitting there, that was kind of a call I needed to hear, that, "yeah, we've acted like we haven't been a part of Baltimore City, the Baltimore Region in forever, and we're shooting ourselves in the foot. Let's make that connection again.”

The UDAT plan invokes this regional connection in two contexts: first, as a means to draw from a gentrified Baltimore by siphoning tourists and new residents from its waterfront; and second, as a way to build connections with regional job providers and transform Dundalk from an industrial to a bedroom community.

Although both strategies recognize regional intradependency, they emphasize the state's role in facilitating private-sector investment. When Dundalk residents and politicians fought a series of "equity regionalist" policies during the prior decade_-affordable housing dispersion, tax-base sharing, and city-county state legislative districts - they had stressed their suspicions of heavy-handed "big government." The UDAT plan's neoliberal regionalism is more palatable to residents: the light hand of the state facilitates cooperation between private and community interests, guides the marketing of their neighborhood, and encourages new private-sector commercial and residential development.

Questions remain about how to make the plan appealing to developers. The UDAT visit, after all, had brought together residents, consultants, and county government in a process that emphasized vision. There were reasons to be optimistic about its realization: the construction of Waterview Homes demonstrated developer interest in the county's eastside, and the DRC's competent leadership secured a series of competitive state grants for revitalization. But developers have so far expressed only a hesitant interest in the UDAT's proposals.

Jim Smith, the current county executive, has attempted to incorporate developers in a new participatory planning process: the Renaissance Pilot Project. Taking Dundalk's UDAT process as its inspiration, the Pilot Project allows each county council district (e.g., Dundalk) to select one site for development. If council approves the site, county government would pay for a site-specific planning process geared toward generating communitydeveloper "consensus" around a buildable, financially feasible design. County government would also offer suspended zoning law on the site and an expedited review process as carrots for developers. When council held public hearings on the proposal in May 2004, residents from around the county expressed misgivings that the vaguely defined "consensus" and suspended zoning ceded too much regulatory ground to developer interests. The only Dundalk residents present, however, were those active in the DRC, and they spoke in support of the legislation. Whether the DRC - whose steering committee includes residents, merchants, institutions, planners, and clergy-represented "the grassroots" may be debatable, but the absence of community groups that so often organize opposition in Dundalk and Essex indicates that this deregulatory move had at least tacit popular approval.

By contrast, the revanchist politics of some Dundalk residents, community groups, and DRC members challenge the moderate positions of the DRC's leadership and the county government, positions that support low-income apartment demolition while providing tenants with compensation. The UDAT plan advocates reallocating space in Dundalk's Village Shopping Center, a strategy that would displace current low-value storefronts (an adult day care center, a LaborReady temp service, a thrift store, a seaman's mission) and convert sixty-two small, second- and third-story Section 8 units into larger, market-rate apartments. Ever since Jim Smith unveiled his Renaissance Pilot Program, the DRC has pursued the clearance of the Yorkway Apartments, the Dundalk parcel included in the 509 
proposal. The DRC leadership and the published UDAT plan justify the clearances with the argument that a revitalized Dundalk Village Shopping Center would require highervalue commercial occupants as well as higher-income tenants and local patrons; but they also insist that some affordable housing must be preserved, and potentially constructed, for "young families." Similarly, the county's Office of Community Conservation has planned to mitigate the effects of displacement in Dundalk as it did in Essex-Middle River, where it made substantial efforts to find tenants' cheap housing nearby and committed over a million dollars to pay off their back rent and utility bills. A neoliberal politics of state retreat and place-marketing here has been mitigated - or more cynically, bought - with some degree of redistribution. These examples of gentrification with compensation are difficult to pigeonhole. They are reminiscent of arguments for "social balance" that have been criticized in critical research (Smith, 2002) as thin, media-friendly disguises for state-backed displacement; indeed, concerns about media coverage and tenant resistance have been a primary motivation for some state and DRC leadership actors. But compensation also reflects the concerns of others who have insisted on dialogue with politically quiescent tenants' groups, proposed a countywide inclusionary housing ordinance, and worked to ensure the viability of local social service providers. Compensatory gentrification thus represents a compromise between neoliberal and progressive voices within the state and the DRC.

More importantly, compensatory gentrification functions as a compromise with those predominantly white, revanchist homeowners who believe that Section 8 residents and "people from the city" are largely to blame for Dundalk's decline. The DRC benefits from the support of these pro-redevelopment constituents but is constantly trying to pull them away from the precipice of explicitly racial, revanchist discourse. Leadership has repeatedly tried to change their discourse by highlighting the need for new, upper-income residents, while attempting to persuade them of the need for affordable housing preservation.

These tensions became unmanageable during a zoning dispute in March 2004. Larry Rosenberg, the developer of the Waterview Apartments in Essex-Middle River, was exploring early plans for a mixed-use development in Dundalk. The parcel consisted of two vacant industrial complexes, a county park with ball fields, and the Yorkway Apartments. Although Rosenberg did not yet have site control, county government petitioned the review board to re-zone the site as mixed-use, permitting a range of construction options, including offices, detached housing, and mid- and high-rise apartments. Impressed by Rosenberg's past work in Essex, DRC representatives prepared to testify in his support at the zoning board's public hearing. They were unaware that a handful of area homeowners had posted and circulated two different "COMMUNITY ALERT" flyers, warning that the ball fields would be cleared to erect subsidized housing. When DRC representatives arrived at the hearing, they were surprised to see an audience of 200, many of whom were angry and worried about the proposed reclassifications.

Exchanges at the meeting, and subsequently on the DRC listserv, made it clear that the debate was not neatly polarized. Residents who were worried about the ball fields spoke against site development at the hearing, even though the re-zoning of the county park was not - as the fliers had erroneously announced - on the meeting's agenda. Residents who saw Section 8 residents and "people from the city" as responsible for local decline were split between opponents who argued that Rosenberg would destroy Dundalk by building high-rise subsidized housing and proponents who claimed that he would save Dundalk by destroying the Yorkway. DRC leadership and several listserv correspondents allied themselves with the latter, while stressing the need to build upscale housing, eliminate "surplus" 
apartments, and break up Dundalk's pockets of concentrated poverty. Leadership worried that foregrounding the elimination of Section 8 units would lead media to characterize redevelopment proponents as "racist yahoos"; instead, they suggested that members emphasize the need for new housing and residents. In the following weeks, the DRC won over several re-zoning opponents but not before Rosenberg was scared away from the site.

\section{The Greater Dundalk Alliance}

The politics of the GDA, by contrast, are often unabashedly revanchist. This partly reflects its composition. Although the memberships of the DRC and the GDA were initially dominated by homeowners - with substantial overlap between the two organizations - the DRC has striven to include local merchants, county planners, social service providers, and clergy, whereas the GDA has remained primarily an umbrella group for homeowners' and neighborhood associations. The GDA's monthly meetings address a broad range of issues, including the local community college, fire protection, and hazardous waste disposal. Few community issues arouse more interest, however, than those related to the outside renters, social service users and providers, and landlords whose behavior has caused the community's decay and prevented its improvement. During the year that I attended meetings, there were regular reports on the number of countyadministered Section 8 tenants by geographic area and apartment complex. Members investigated the placement of halfway houses for recovering alcohol and drug addicts. Most recently, the president, representing the association, requested the metropolitan transit authority reduce the number of bus stops in Dundalk and curtail its schedule, citing noise issues; in GDA meetings, she speculated that late night schedules do not serve local workers but rather bring "the wrong element" into the community.

Several developers also presented plans for new housing before the GDA. Among them was Kevin Carney, who had approached Dundalk's councilman about re-zoning for a parcel along the mostly industrial Peninsula Expressway. His development plan proposed converting a dilapidated industrial dock into a potentially gated 162-unit residential, boutique commercial, and marina complex. The councilman insisted that Carney first make a presentation to community groups, and the developer appeared at the GDA meeting in February, 2004.

Throughout his presentation, Carney wove together a keen awareness of local revanchist politics with other pro-gentrification discourses. Sheltered Harbor Apartments would reclaim suburban space for Dundalk homeowners and their children while emphatically excluding Section 8 tenants, reversing the local decline attributed to the departure of baby boomers and the influx of people from the city. The presenter made this clear at the outset:

We would like to build 162 units of luxury elevator apartments on this site, renting for about $\$ 1300$ a month. They will not be subsidized housing. We plan to market the apartments to three groups. First, people who want to stay in Dundalk, who own their home free and clear, [. . .] but don't want stairs, don't want to do maintenance. [. . .] Another group is the children of that generation, who rent in [newer suburbs] and who would love to come back if they could find housing to meet their needs. The third group is boat owners [. . ] we're working to fix up the site and build a marina with 80 piers, because we think we could entice boat owners from Canton; those folks could have a boat here and not pay 450 dollars a month for a slip. 
When one audience member asked whether luxury apartments would sell in an area that was still primarily industrial, Carney responded:

To be honest, it scares me. I mean, we're trailblazing here. We believe that with all the new residential development down there, we'll overcome the industrial uses, and the area will be - and I use this word in a positive sense - gentrified.

Another audience member noted that the prospective developer of an adjacent proposed community had included assisted-living units for the elderly and had received low-income housing tax credits. Amid some audience disagreement about whether that development posed a serious threat, he warned Carney that:

\begin{abstract}
... people can come into here and say they're building assisted living and they take tax credits and have to take all kinds of people, you know, drug addicts - I mean, I wouldn't want to see you build this and then you have drug dealers and [public assistance] recipients across the street.
\end{abstract}

Carney: [with a short laugh] Me neither! You'd have an ally here!

Those assembled were impressed. At the end of the presentation, the GDA president offered to write a letter in support of the project, and several audience members gave Carney's plan high praise. "This is exactly what Dundalk needs!" gushed one resident. "I've been volunteering downtown for 6 years. I drive down Boston Street [in Canton] and what a vision I saw come to life!" Another expressed her ardent belief that the development would be "the start of all good things for this community." These compliments are not incidental. Given Dundalk's unproven upscale housing market, the demonstrated past power of Dundalk's community organizations, and the state's insistence on community input, development projects such as Rosenberg's and Carney's are highly sensitive to resident support or opposition.

\title{
Resistance to Gentrification
}

As initial plans for newbuild and replacement housing have been presented, there has been surprisingly little worry among the politically active that they could become the victims of displacement. Antigentrification discourse has been present, but sporadic. In the case of the DRC-backed Rosenberg plan, one opponent of reclassification expressed her fear that developers had carte blanche to take homeowners' property; other DRC members responded with patronizing explanations of eminent domain law (i.e., that only the state could take land) but evaded the legitimate question of what property rights meant in post-509 Baltimore County. Another Rosenberg opponent suggested that rather than mixed-use development, a new box factory should be built to employ residents. The ambivalence of Dundalk residents who value or rely on local industrial employment represents an important source of unresolved community tension (cf. Curran, 2004).

Residents of Turner Station, the African American enclave, have also expressed ambivalence about the planned revitalization. Several attended the UDAT community input meetings, and one particularly committed activist has continued to be active in the DRC. Their participation led to several proposed improvements in the Turner Station area-a new cultural center, ecological park, streetscaping, and nearby loft housing (which some believe will provide housing opportunities). By contrast, renter households 
comprise more than half of Turner Station's population, and many in the neighborhood's Day Village - a complex of low-rent, waterfront townhomes - worry about the consequences of encroaching gentrification.

Beyond the threat of outright condemnation and clearance, there are some concerns that rising home prices and property taxes would price out moderate-income families. At the level of organizational leadership, this is manifest as disagreement between the DRC and the GDA. The DRC advocates marketing most of Dundalk's housing as starter homes for younger families, whereas the GDA believes that Dundalk's homes could easily rival the high property values of Canton and should be marketed to professionals.

The GDA's position has periodically provoked objections from individual members. Six months after Carney made his proposal, the GDA president informed the audience that the apartments were now planned as luxury condominiums. Although she reiterated Carney's plan to market the units to Dundalk residents, their children, and Canton boatowners, one retiree was skeptical: "We're not rich people down here. We lost our skin in the industrial downturn. Now I hear about these places costing $\$ 250,000$ - people down here can't afford to buy these places at $\$ 250,000$ ! Who's coming in here to buy these? It's not people from Dundalk!" Another resident worried about the effect of new development on her property taxes. Leadership assured both of them that, "whenever an area gets gentrified, property values go up," compensating for high taxes with equity and giving present owners and their children access to the new housing. Neither resident was convinced.

Such reservations have not yet cohered into any organized campaign to preserve rental stock, industrial employment, or housing affordability. Outside of Turner Station, local tenant organizations are weak or nonexistent. Unions and political clubs, which once buttressed a complex class identity and fought for worker, homeowner, and tenant interests, have so far remained largely disengaged from gentrification planning. Certainly the pro-development consensus articulated by community leaders and the state - whether articulated as pro-gentry or antirenter-leaves little room for individual dissenting voices, including those of low-income renters who might be otherwise inclined toward political participation.

\section{CONCLUSION}

The purple cover of the published UDAT plan promises "a second century vision," and indeed, the full-color photographs and plats inside reflect an optimism that is hard to criticize. They represent the hard work of residents and planners, who have tried to find solutions for seemingly intractable problems. For thirty years, Dundalk has suffered from deindustrialization and demographic changes that have deepened political divisions between the community's residents. How do residents and local institutions rebuild their community, if not by gentrification?

In this paper, gentrification has been conceived as a growth strategy that supposedly improves places by removing problem people and land uses and replacing them with better ones. Other economic development strategies could provide a more balanced approach that would avoid the displacement and exclusion that often accompany urban gentrification. Although they can only be mentioned here, such initiatives would aim to keep more housing affordable and improve job quality. Countywide inclusionary zoning ordinances along the lines of the Montgomery County, Maryland model would require that developers set aside some portion of new development for low- and moderate-income units. Linkage fees on prime commercial real estate (e.g., the county's heavily promoted Route 43 
corridor) would fund affordable housing construction. To raise the wages of residents, the county would expand training programs at the community college and match laid-off and low-wage employees with the high-skill and high-wage jobs that the county is trying to attract to the Route 43 corridor. Local nonprofits and unions would operate a joint housing and worker resource center designed to help workers improve their skills, wages, and working conditions and help renters and homeowners improve their housing's quality and affordability.

Are strategies like these politically viable? The reasons for gentrification's popularity that have been discussed here reflect the limits that proposals for economic development face in many industrial suburbs. Over the long term, the ascendancy of homeowner organizations, growing hostility toward welfare programs and recipients, and deepening political divisions along the lines of class, race, and housing tenure have provided much better soil for revanchist public policies than for affordability-oriented ones. Over the medium and short term, the very visible spread of gentrification-promoted by local governments and funded by inward-turning developers- has begun to popularize gentrification at the grassroots. Along these broad contours, Dundalk's history and present politics resemble those of other industrial suburbs. Nevertheless, variations in political history, demographic change, and metropolitan context might create different fields of opportunity. We must ask not just whether balanced development is politically feasible but where it is feasible, and this will require further research.

Dundalk, for its part, offers reasons for pessimism. Most industrial suburbs may be hostile to government involvement in affordable housing provision, but Dundalk's past resistance to the MTO makes it doubly so. Most industrial suburbs may be close enough to be captivated by gentrified neighborhoods over the city line, but Dundalk stands downstream from one of the most lauded and emulated redevelopment projects in the country. Moreover, Baltimore County's housing prices and tax rate are low, by national standards, and the threats that runaway prices and rising assessments pose to homeowners seem distant enough to be chimerical. Given this context, the county's compensatory gentrification approach might appear the best one possible.

But not all Dundalk residents are revanchist, not all of them are homeowners, and the local discourse around housing should not be taken as pregiven. Changing local discourse could begin with greater attention to resident representation and information. If tenants have been quiescent and their advocates drowned out, state actors should at least bring them to the table and actively solicit their input in charting the community's future. Homeowners and renters alike should also be told about the shortcomings of urban gentrification as a redevelopment strategy. Conversely, models of successful, balanced growth should be publicized. External legal solutions - such as the ACLU lawsuit in Baltimore, MD, or the Department of Justice suit in Addison, IL - are far less promising unless somehow tied to local community organizing efforts; otherwise, they provide limited remedies at the cost of scarring local resentments. Furthermore, media coverage over the backlash to these remedies may portray white supremacy and white privilege as concentrated in the industrial suburbs, offering political cover to far wealthier suburbs where public housing is limited by exorbitant housing prices and quieter (but quite effective) forms of homeowner activism. Change must come from the ground up and will have to begin with the difficult work of creating political alliances across the trenches of race and class that run through places like Dundalk.

Whether or not we can "do better" than gentrification, arguments between those who envision gentrification as driven by capitalists and those who envision it as driven by gentrifiers must be reframed. As gentrification diffuses to new locations, homeowners like 
those in Dundalk can become gentrification's most enthusiastic advocates and can hold considerable power within new coalitions between developers, states, and communities. Working-class suburban consent suggests that the global growth strategy (Smith 2002) engineered by economic and political elites is becoming a hegemonic form of economic development with ever-deeper political roots. The industrial suburbs, in short, present a new challenge to critical observers inside and outside the academy: that of residents who face gentrification, not with rebellion or resignation but with hope.

ACKNOWLEDGMENT: The author thanks Teresa Sharpe, Rita Gaber, Amy Hanser, Jenna Loyd, C. J. Pascoe, Margaret Weir, Richard Walker, three anonymous reviewers, and two Dundalk residents for their helpful critiques and suggestions. Any mistakes or mischaracterizations are mine alone.

\section{REFERENCES}

Baltimore County Office of Community Conservation and Office of Planning (2003). Dundalk, Maryland: A second century vision. Dundalk, MD: Dundalk Renaissance Corporation.

Betancur, J. (2002). The politics of gentrification: The case of West Town in Chicago. Urban Affairs Review 37 (6), 780-814.

Brenner, N., \& Theodore, N. (2002). Cities and the geography of "actually existing neoliberalism." In N. Brenner \& N. Theodore (Eds.), Spaces of neoliberalism: Urban restructuring in North America and Western Europe (pp. 2-32). Malden, MA: Blackwell Publishing.

Bridge, G. (1995). The space for class? On class analysis in the study of gentrification. Transactions of the Institute of British Geographers 20 (2), 236-247.

Brooks, W. (2004). Tape recorded interview by author. April 28.

Carlson, J. (1981). George C. Wallace and the politics of powerlessness: The Wallace campaigns for the presidency, 1964-1976. New Brunswick, NJ: Transaction Books.

Cisneros, H. G. (1996). The transformation of America's public housing: A 1996 status report. Washington, DC: U.S. Department of Housing and Urban Development.

Crump, J. R. (2003). The end of public housing as we know it: Public housing policy, labor regulation, and the U.S. city. International Journal of Urban and Regional Research 27 (1), 179-187.

Curran, W. (2004). Gentrification and the nature of work: Exploring the links in Williamsburg, Brooklyn. Environment and Planning A 36 (7), 1243-1256.

Dreier, P. (1982). The status of tenants in the United States. Social Problems 30 (2), 179-198.

Durr, K. (2003). Behind the backlash: White working-class politics in Baltimore, 1940-1960. Chapel Hill: The University of North Carolina Press.

Edsall, T. B., \& Edsall, M. D. (1991). Chain reaction: The impact of race, rights, and taxes on American politics. New York: W. W. Norton.

Formisano, R. P. (1991). Boston against busing: Race, class, and ethnicity in the 1960s and 1970s. Chapel Hill: University of North Carolina Press.

Gainsborough, J. F. (2001). Fenced off: The suburbanization of American politics. Washington, DC: Georgetown University Press.

Goetz, E. G. (2003). Clearing the way: Deconcentrating the poor in urban America. Washington, DC: Urban Institute Press.

Hackworth, J. (2002). Postrecession gentrification in New York city. Urban Affairs Review 37 (6), $815-843$.

Hackworth, J., \& Smith, N. (2001). The changing state of gentrification. Tijdschrift Voor Economische En Sociale Geografie 92 (4), 464-477.

Harris, R. (1990). Working-class homeownership in the American metropolis. Journal of Urban History 17 (1), 46-69.

Hartigan, J., Jr. (1999). Racial situations: Class predicaments of whiteness in Detroit. Princeton: Princeton University Press. 
Harvey, D. (1989). From managerialism to entrepreneurialism: The transformation in urban governance in late capitalism. Geografiska Annaler B 71 (1), 3-17.

Hays, R. A. (1995). The federal government and urban housing: Ideology and change in public policy. Albany: State University of New York Press.

Hudnut, W. H. I. (2003). Halfway to everywhere: A portrait of America's first-tier suburbs. Washington, DC: The Urban Land Institute.

Katz, C. (2002). Stuck in place: Children and the globalization of social reproduction. In R. J. Johnston, P. J. Taylor, \& M. J. Watts (Eds.), Geographies of global change: Remapping the world (2nd ed., pp. 248-260). Malden, MA: Blackwell.

Katz, M. B. (1989). The undeserving poor: From the war on poverty to the war on welfare. New York: Pantheon Books.

Katznelson, I. (1981). City trenches: Urban politics and the patterning of class in the United States. Chicago: University of Chicago Press.

Kornblum, W. (1974). Blue collar community. Chicago: University of Chicago Press.

Lee, S., \& Leigh, N. G. (2005). The role of inner ring suburbs in metropolitan smart growth strategies. Journal of Planning Literature, 19 (3), 330-346.

Lees, L. (1994). Gentrification in New York and London: An Atlantic gap? Housing Studies 9 (2), 199-217.

Lees, L. (2000). A reappraisal of gentrification: towards a 'geography of gentrification.' Progress in Human Geography 24 (3), 389-408.

Levine, M. A. (2004). Government policy, the local state, and gentrification: The case of Prenzlauer Berg (Berlin), Germany. Journal of Urban Affairs 26 (1), 89-108.

Levine, M. V. (1987). Downtown redevelopment as an urban growth strategy: A critical appraisal of the Baltimore renaissance. Journal of Urban Affairs 9 (2), 103-123.

McGirr, L. (2001). Suburban warriors: The origins of the new American right. Princeton: Princeton University Press.

Mele, C. (2000). Selling the lower east side: Culture, real estate, and resistance in New York City. Minneapolis: University of Minnesota Press.

Merrifield, A. (2002). Dialectical urbanism: Social struggles in the capitalist city. New York: Monthly Review Press.

Nelson, B. (2001). Divided we stand: American workers and the struggle for Black equality. Princeton: Princeton University Press.

Newman, K. (2004). Newark, decline and avoidance, renaissance and desire: From disinvestment to reinvestment. Annals of the American Academy of Political and Social Science, 594, 34-48.

Newman, K., \& Ashton, P. (2004). Neoliberal urban policy and new paths of neighborhood change in the American inner city. Environment and Planning A 36 (7), 1151-1172.

Nicolaides, B. M. (2002). My blue heaven: Life and politics in the working-class suburbs of Los Angeles, 1920-1965. Chicago: University of Chicago Press.

Omi, M., \& Winant, H. (1994). Racial formation in the United States: From the 1960s to the 1990s. New York: Routledge.

Peterman, W. (2000). Neighborhood planning and community-based development: The potential and limits of grassroots action. Thousand Oaks, CA: Sage Publications.

Poindexter, G. C. (2000). Beyond the urban-suburban dichotomy: A discussion of sub-regional poverty concentration. Buffalo Law Review 48 (1), 67-82.

Rusk, D. (1999). Inside game, outside game: Winning strategies for saving urban America. Washington, DC: Brookings Institution Press.

Slater, T. (2002). Looking at the 'North American City' through the lens of gentrification discourse. Urban Geography 23 (2), 131-153.

Smith, N. (1992). Contours of a spatialized politics: Homeless vehicles and the production of geographical scale. Social Text 32, 54-81.

Smith, N. (1996). The new urban frontier: Gentrification and the revanchist city. London: Routledge. 
Smith, N. (2002). New globalism, new urbanism: Gentrification as global urban growth strategy. In N. Brenner \& N. Theodore (Eds.), Spaces of neoliberalism: Urban restructuring in North America and Western Europe (pp. 80-103). Malden, MA: Blackwell Publishing.

Smith, N., \& DeFillipis, J. (1999). The reassertion of economics: 1990s gentrification in the lower east side. International Journal of Urban and Regional Research 23 (4), 638-653.

Smith, N., Caris, P., \& Wyly, E. (2001). The 'Camden Syndrome' and the menace of suburban decline. Urban Affairs Review 36 (4), 497-531.

Stoecker, R. (1997). The CDC model of urban redevelopment: A critique and an alternative. Journal of Urban Affairs 19 (1), 1-22.

Sugrue, T. (1996). The origins of the urban crisis: Race and inequality in postwar Detroit. Princeton: Princeton University Press.

U.S. Bureau of the Census. (1952). Census tract statistics: Baltimore, Maryland and adjacent area, 1950 census report. Washington, DC: U.S. Government Printing Office.

U.S. Bureau of the Census. (1962a). Census of population: 1960, characteristics of the population, Maryland. Washington, DC: U.S. Government Printing Office.

U.S. Bureau of the Census. (1962b). U.S. censuses of population and housing: 1960, census tracts: Final Report PHC(1)-13 (Baltimore, MD). Washington, DC: U.S. Government Printing Office.

U.S. Bureau of the Census. (1972). 1970 census of population and housing, census tracts, final report PHC(1): Baltimore, Maryland standard metropolitan statistical area. Washington, DC: U.S. Government Printing Office.

U.S. Bureau of the Census. (1973). 1970 census of population, characteristics of the population, Maryland. Washington, DC: U.S. Government Printing Office.

U.S. Bureau of the Census. (1982). 1980 census of population, characteristics of the population, general population characteristics, Maryland. Washington, DC: U.S. Government Printing Office.

U.S. Bureau of the Census. (1983). 1980 census of population and housing, census tracts, Baltimore, MD. Standard metropolitan statistical area. Washington, DC: U.S. Government Printing Office.

U.S. Bureau of the Census. (1992a). 1990 census of population, general population characteristics, Maryland. Washington, DC: U.S. Government Printing Office.

U.S. Bureau of the Census. (1992b). Census of population and housing, 1990: Summary tape file 3. Retrieved on April 27, 2005 from http://factfinder.census.gov.

U.S. Bureau of the Census. (2001). Census 2000 summary file 1 - Maryland [online]. Retrieved on April 27, 2005 from http://factfinder.census.gov.

U.S. Bureau of the Census. (2002). Census 2000 summary file 3 - Maryland [online]. Retrieved on April 27, 2005 from http://factfinder.census.gov.

Vale, L. J. (1995). The imaging of the city: Public housing and communication. Communication Research 22 (6), 646-663.

Wilson, D., Wouters, J., \& Grammenos, D. (2004). Successful protect-community discourse: Spatiality and politics in Chicago's Pilsen neighborhood. Environment and Planning A 36 (7), 1173-1190.

Wyly, E., \& Hammel, D. (1999). Islands of decay in seas of renewal: Housing policy and the resurgence of gentrification. Housing Policy Debate 10 (4), 711-771.

Wyly, E., \& Hammel, D. (2004). Gentrification, segregation, and discrimination in the American urban system. Environmental and Planning A 36 (7), 1215-1241. 